\title{
Unexpected Lives: The Intersection of Islam and Arab Women's Entrepreneurship
}

\begin{abstract}
This paper explores how Islam is understood by Muslim women entrepreneurs and considers its influence on their entrepreneurial experiences in the country-specific context of Lebanon. In so doing, we adopt a qualitative interpretative approach, drawing upon 21 in-depth, semi-structured interviews with women entrepreneurs. Accordingly, we present empirical evidence detailing how Muslim women entrepreneurs utilise various aspects and teachings of Islam to make sense of their entrepreneurial decisions within the context of restrictive social and cultural practices. We thus provide insight into how women's entrepreneurship interlocks with Islamic teachings and the restrictions imposed by patriarchal sociocultural values within the country-specific context of Lebanon. This paper advances entrepreneurship research by demonstrating how Islam unfolds as a source of inspiration and resilience for women entrepreneurs, if and when equipped with an Islamic feminist interpretation.
\end{abstract}

Keywords: Islam; Women's entrepreneurship; Structuration theory; Islamic feminism; Lebanon.

\section{Introduction}

Research focusing on how religion influences and is influenced by entrepreneurship is somewhat limited (Dana 2009; Murtaza et al. 2016; Uygur 2009; Tlaiss 2015a). This suggests that entrepreneurship research might have overlooked an important driver of entrepreneurial action in modern life (Smith et al., in press), despite Weber (1930), almost a century ago, stressing the link between entrepreneurial efforts and deep, religious hopes and fears. Although the paucity of research in the entrepreneurship discourse may stem from the general sensitivity of the topic in the business context, it is further accentuated in the case of Islam, which has been negatively associated with successful entrepreneurship (Kuran 2003, 2004) and portrayed as a major contributor to the systematic subordination of women (Tlaiss 2015a, Tlaiss 2015b). Accordingly, an emerging body of knowledge has begun to address this void via research that demonstrates the conduciveness of Islam to enterprise (Gümüsay 2015; Hammoudeh 2012), the importance of Islamic business and work ethics for Muslim entrepreneurs (Beekun and Badawi 2005; Karakas et al. 2015; Murtaza et al. 2016; Possumah et al. 2013; Uygur 2009) and the positive influence that Islam plays in the lives of Muslim women (Essers and Benschop 2009; Tlaiss 2015b).

However, to date, few studies have critically and empirically explored the intersection of Islam, Muslim women and entrepreneurship, particularly within contexts constrained by restrictive cultural practices (Madichie and Gallant 2012; Tlaiss 2015a). Consequently, there is a significant gap in understanding with regards to how Muslim women entrepreneurs understand and interpret Islam in relation to their engagement with entrepreneurship and Islam's influence (if any) on the various aspects of their entrepreneurial experiences. This gap is of both managerial and theoretical importance given the distinctiveness of a religious perspective on entrepreneurship, which focuses on specific scriptural sources, meta-physical objectives and detailed practices that can complement and enrich entrepreneurship theory and practice (Gümüsay 2015).

Accordingly, the aim of this paper is to explore how Islam is understood by Muslim women entrepreneurs and its influence on their entrepreneurial experiences in the country- 
specific context of Lebanon, which is within the larger context of the Arab Middle East. To achieve this aim, we follow a qualitative interpretative methodology, drawing upon 21 in-depth, semi-structured interviews with women entrepreneurs based in Lebanon. Given the heterogeneity of Islam and the different interpretations of Islam across national contexts (Karakas et al. 2015; Uygur 2009), we adopt structuration theory as our theoretical lens (Giddens 1984). Such an adoption allows us to glean a nuanced understanding of how Muslim women entrepreneurs in modern society exercise their agency, within structures of socio-cultural values. In other words, a multidimensional characterization of today's modern world that acknowledges structure, brings capitalist production together with issues of gender but does not preclude effective action (Whittington 1992). Indeed, Giddens (1984) insists on the potential for human agency and reflexivity to solve conflicts between the dimensions of structure through choosing actions deliberately and executing them effectively, even, in defiance of the rules and structure. Accordingly, we do not seek to understand the objective truth but rather Islam's influence on the entrepreneurial experiences of its female followers in Lebanon. As we conduct this exploratory study, we realise that Islam is but one of many intersecting structural features of Lebanese society. Furthermore, we do not use women as a generic proxy for gender (Henry et al. 2015) or as the embodiment of the gendered subject (Marlow et al. 2018). On the contrary, we challenge the notion that women are synonymous with gender, and only women have a gender (Kelan 2009). Instead, we approach gender as a multiplicity of fluid social ascriptions, which are socially constructed assumptions stereotypically associated with sex categories (Marlow et al. 2018). Gender, therefore, is a performative (Butler 1993) and a situated social practice, best explored through its intersection with other social constructs, such as religion (Essers and Benschop 2009).

In this paper, we make the following contributions to theory. First, we contribute to research on Islamic entrepreneurship by extending prior research which has been predominantly theoretical and normative in nature (Gümüsay 2015; Possumah et al. 2013). In so doing, we demonstrate how an Islamic feminist interpretation of Islamic teachings can provide women entrepreneurs with creative solutions to support their entrepreneurial ambitions in the context of adverse economic, political and socio-cultural conditions. Second, we contribute to women's entrepreneurship by widening our understanding of entrepreneurship and entrepreneurial behaviour beyond the normative stereotype of the entrepreneur as a white, middle-class, middle-aged male (Marlow et al. 2018). By acknowledging the many different interpretations of Islam across national contexts (Karakas et al. 2015) and looking beyond women entrepreneurs in developed economies (McAdam 2013; Marlow et al. 2018), we expand and advance knowledge of women's entrepreneurship outside European and North American contexts. We also attend to scholarly calls to understand the various interconnections of Islam and entrepreneurship in diverse social and cultural contexts and at the country level (Karakas et al. 2015; Uygur 2009; Tlaiss 2015b). In so doing, we provide insight into how women's entrepreneurship interlocks with Islamic teachings and the restrictions imposed by patriarchal sociocultural values within the country-specific context of Lebanon. Third, we contribute to research on resilience and entrepreneurship (Branzei and Abdelnour 2010; Dewald and Bowen 2010), particularly the emerging body of knowledge on the forms and nature of individual entrepreneurs' resilience (Bullough et al. 2014). Notwithstanding the distinct aspects of entrepreneurship associated with entrepreneurial resilience (Hayward et al. 2010; Ungar et 
al. 2007), we extend current research by demonstrating how Muslim women entrepreneurs utilise their interpretations of Islam and its teachings to justify and make sense of their entrepreneurship endeavours within the context of adverse socio-cultural barriers and masculine stereotypes.

To develop these arguments, we commence by outlining the rationale for our theoretical framing, followed by a discrete analysis of the key constructs-Islam, entrepreneurship and gender. We then outline structuration theory to draw these concepts together, which then forms the basis of our empirical illustration of the analysis. In the following section, we discuss our methodological rationale and method. This discussion forms the basis of our theoretical contributions and provokes further investigation to conclude the paper.

\section{Theoretical Framing}

\section{Islam}

Despite the recognised influence of Islam on contemporary societies, Islam and its relationship with entrepreneurship has been significantly neglected (Kayed and Hassan 2010; Roomi and Harrison 2010), with it often portrayed as unsupportive to entrepreneurship (Kuran 2004). Indeed, Islam and Islamic regulations are often blamed for environments unconducive to increased productivity, growth and economic development (Gümüsay 2015). For instance, Max Weber (1905) described Islam as a religion that failed to provide sufficient awareness to positively influence economic attitudes, behaviours and development and, therefore, acted as a barrier to capitalist development. Similarly, slower economic development has often been attributed to regulations shaped by Islamic teachings, whereas Westernisation has been posited as a prerequisite for modernisation (Kayed and Hassan 2010). Given that Islam is the world's second largest monotheistic religion and the fastest growing religion in the world (Gümüsay 2015; Murtaza et al. 2016), in-depth empirical engagement with Islam and entrepreneurship is warranted and, indeed, timely for the advancement of the entrepreneurship domain.

Islam is built around five pillars that constitute the religion's core creed and its followers' minimum obligations. The pillars include acknowledgement of only one God (Allah in the Arabic language) and of the Prophet Mohammed (PBUH*) as the last prophet to humankind, along with praying, fasting, almsgiving and pilgrimage (Tlaiss 2015a). The primary sources of Islamic principles, in addition to Shariah or Islamic law, are the Holy Quran and the Sunnah (Basit 2012; Beekun 2012). The Quran is the verbatim word of Allah as revealed to the Prophet (PBUH). It outlines values and principles that organise and govern its followers' lives, work, relationships and business dealings, including entrepreneurial endeavours (Gümüsay 2015). The Sunnah or the Hadeeth presents the words, actions and behaviours of Mohammed (PBUH). As the embodiment of morality in Islam (Basit 2012), the Prophet (PBUH) is a considered a 'quintessential role model' for all Muslims (Beekun and Badawi 2005, p.133). Nevertheless, Mohammed's morality and virtuous behaviours have been questioned in the literature based on his ownership of slaves (Gordon 1989), treatment of enemies, and his marriages (Willis 1985).

To its followers, Islam is 'a way of life, not just a religion' (Beekun and Badawi 2005, p.143). The values promoted in the Holy Quran and the Sunnah are presumed by Muslims to be universal, not subject to change and nullification, applicable to every field 
of life and valid for all times and places, regardless of whether Muslims' lived behaviours align with them (Murtaza et al. 2016). Collectively, the Quran and Hadeeth provide guidance and details governing the various aspects of human life, including family affairs such as marital life, relationships with parents and children, as well as inheritance, business transactions, value systems and ethics, social relationships, politics, and even military tactics (Kayed and Hassan 2010; Tlaiss 2015a).

\section{Islam and entrepreneurship}

Although Islam does not offer a concrete theory of entrepreneurship (Kayed and Hassan 2010), it does provide 'a foundation and a framework' (Gümüsay 2015, p.199-201). Work is strongly emphasized in the Muslim faith as more than 50 verses in the Quran stress the centrality of work to the lives of individuals and the prosperity of communities, with work strongly aligned with faith (Possumah et al. 2013). In particular, Islam emphasises quality of work, excellence (Hammoudeh 2012; Tlaiss 2015b) and an equitable approach to dealing with various stakeholders (Beekun and Badawi 2005). Islam considers commercial activity to be a divine calling, a necessary aspect of human life and a source of social fulfilment and psychological pleasure (Ali and Al Owaihan 2008). The Quran clearly states that 'God hath permitted trade and forbidden usury' $\left(2: 275^{* *}\right)$. Teachings throughout the Quran and the Hadeeth guide work dynamics and promote values that govern business ventures and dealings with stakeholders. These values, such as honesty, loyalty, fairness and justice, are perceived as ethical and conducive to the development of trade and commerce (Murtaza et al. 2016; Possumah et al. 2013; Uygur 2009). Muslim entrepreneurs are thus expected to conduct all their business dealings in accordance with Islamic teachings (Beekun 2012). For instance, Muslim entrepreneurs are expected to promote cooperation and generosity, and to focus on good moral values such as honesty and fairness to meet religious expectations and avoid punishment from God (Beekun 2012; Hammoudeh 2012; Ismaeel and Blaim 2012). Furthermore, Prophet Mohamad's (PBUH) occupation as a merchant and trader and frequent references to merchants and traders in the Quran and Hadeeth (Ali and Al Owaihan 2008), indirectly contribute to endowing entrepreneurship with a sense of nobility or significance in the Muslim faith (Beekun and Badawi 2005; Ismaeel and Blaim 2012).

\section{Islam, gender and entrepreneurship}

Gender equality in the Arab countries continues to lag behind the rest of the world (Kostenko et al. 2016; Norris and Inglehart 2002) and as such, hinders the development of this region (Norris 2009). The gender discrimination faced by women in Muslim-majority countries has often been attributed to Islam, as being a religion that reinforces gender differences by granting men pre-eminence and authority over women in financial responsibility, inheritance, marriage and divorce (Karmi 1996; Kazemi 2000). Islamic traditions in the Arab societies have been described as having a lasting impact on contemporary social values (Norris and Inglehart 2002), including support for gender equality (Norris 2009). Hence, Islam has been considered to be a major, if not the most important, contributor to the systematic subordination of women in patriarchal Arab societies (Tlaiss 2015b). To that effect, previous studies (Norris 2009; Norris and Inglehart 2002), found that people in Muslim societies are still conservative with respect to gender attitudes and that Islam is a predictor for patriarchal values. In fact, various datasets 
(including WVS and Arab Barometer) support this claim by providing evidence that Islamic countries report the lowest support for women equality and autonomy, and women's equal rights with regards to employment. For example, using data from the six countries covered by the first wave of the Arab Barometer project, Kostenko et al. (2016) found that many people, especially males aged 25-35yrs, despite being better educated are more conservative (against democracy and gender equality) in comparison to a small group (about $17 \%$ of the population) of elderly and middle-aged women and men who support both. The persistent descriptions of gender inequality and discriminatory practices against Muslim women in Arab societies are primarily fuelled by extreme Muslim conservative interpretations of religious texts and by socio-cultural values promoting gender stereotypes, gender roles, and patriarchal, masculine traditions often mistakenly regarded as Islamic in nature (Al-Dajani and Marlow 2010; Madichie and Gallant 2012; Tlaiss 2015a,b).Consequently, a strong narrative focused on the interlocking of Islam and women's challenges with regards to entrepreneurship has emerged (Karmi 1996; Kazemi 2000).

However, a small but growing number of empirical studies has started to challenge this narrative through focusing on the intersections of faith and entrepreneurship (Roomi and Harrison 2010; Smith et al. in press; Tlaiss 2015a). For example, in the context of Christianity, Smith et al. (in press) posited that the likelihood of identifying business opportunities increases when individuals possess religious knowledge and motivation based on religious development, identity salience, and personal calling. Also, in the context of Christianity, Cornwall and Naughton (2003) drew on the Catholic tradition to reconceptualise entrepreneurial success through focusing on virtue rather than financial gains, while Parboteeah et al. (2015) explored the influence of Christianity on knowledge investments and as a driver of entrepreneurship.

With regards to the intersection of Islam with women's entrepreneurship, a nascent stream of research is emerging which focuses on the influence of Islam on entrepreneurship beyond the narrow focus of portraying Muslim women's entrepreneurship as problematic and obstacle-laden (Tlaiss 2015a) or Islamic business ethics (Beekun 2012; Beekun and Badawi 2005; Possumah et al. 2013). For example, Roomi and Harrison (2010) revealed that women's entrepreneurship in the context of Islamic Pakistan is not hindered by Islamic teachings but rather can be further enhanced per these teachings. Similarly, Muslim Moroccan and Turkish female entrepreneurs in the Netherlands referred to Islam as enabling their entrepreneurial progress as they moved away from dogmatic interpretations of Islam to more liberal approaches (Essers and Benschop 2009). In other empirical studies in the United Arab Emirates (Madichie and Gallant 2012) and Jordan (Al-Dajani and Marlow 2010), Arab Muslim women reported facing prohibitions imposed by societal socio-cultural teachings and masculine, traditional interpretations of Islam rather than by Islam itself.

Despite the increasing number of women entrepreneurs in Lebanon and the larger Arab Middle East (Tlaiss and Kauser 2018), we know little about the intersection of Islam with their entrepreneurial endeavours. It is, therefore, in this context that this exploratory research aims to glean understanding into how Islam is understood and the role it plays in the entrepreneurial experiences of Muslim women entrepreneurs in the country-specific context of Lebanon. 


\section{Structuration theory and Islamic feminism as our theoretical lens}

In this paper, our focus is not Islam itself but on how it is understood and interpreted by Muslim women entrepreneurs and how these interpretations influence their entrepreneurial experiences. This is crucial given that although all Muslims read the same Quran, they interpret it differently, hence the various schools in Islamic thinking and theology, and the diverse forms of Islam that are all considered "equally real" (Asad 1986, p.2). Accordingly, we draw on structuration theory, which argues that social systems, constituted by humans, are enabled and constrained by the social structural properties of these systems (Whittington 1992). However, these structures simultaneously define the rules guiding action and the resources empowering action (Whittington 1992). This theory also posits that the creation and reproduction of social systems is based on the analysis and intersection of the mutually dependent structure (Islam) and the agents (Muslims) (Whittington 2010). However, the structure (Islam) is a duality, 'both medium and outcome of reproduction of practices' (Giddens 1984, p.5). Hence, social actors not only bring it into being, but also continually re-create human social activities (Giddens 1984). As Giddens argues, '[i]n and through their (social) activities agents reproduce the conditions that make these activities possible' (1984, p.3). The agency of the entrepreneurs in this study, therefore, is crucial in the production of societal structures through social practices (Uygur 2009); with agency exercised as the entrepreneurs follow or reject the rules of Islam and the associations of meanings with Islam. Structuration thus happens as the agents (Muslims) draw on the various rules and resources of their structure (Islam) and, in doing so, either reproduce the structural (Islamic) principles initially organising their activities or amending and changing those principles according to their own agency.

Given our interest in the relative rather than absolute meaning of Islam, (i.e., how the Muslim women entrepreneurs understand and interpret), we also capitalize on Islamic feminism. Islamic feminism is often understood as a religiously grounded discourse which takes the Quran as its central text (Badran 2005). Islamic feminists (Ahmed 1992; Badran 2005, 2009; Barlas 2002; Mernissi 1991, 1996; Wadud 1999) believe that the Quran, is the word of Allah that transcends time, emphasizes gender egalitarianism, confirms the equality of men and women, and is devoid of misogynistic verses. They also believe that the Quran, which is polysemous and open to multiple interpretations (Badran 2005), has been decontextualized from its original historical and literary context and recontextualized in other cultures based on various ideological needs (Arkoun 1994; Wadud 1999). In other words, after the demise of the Prophet, male Muslim scholars began what is commonly known as ijtihad (the use of independent reasoning not precisely covered by Quran and Hadeeth) to clarify issues pertaining to the role and position of women in society, thus unintentionally and intentionally establishing self-serving interpretations that further cemented the patriarchy that predated Islam and existed in what came to be Muslim societies. Islamic feminists therefore seek to debunk, unread, and deconstruct the legitimacy of patriarchy from Islam (Barlas 2002; Badran 2005, 2009) given their genuine belief that it is not the Quranic text that has restricted women but rather the interpretations of the Quran (Mernissi 1996; Wadud 1999). In doing so, they refuse the reductionism of Islamic texts and the orthodox, conservative, masculine exegeses (Wadud 1999). Alternatively, they rely on their own interpretation of the Islamic texts through focusing on 
the ethical reading of the Quran and Hadeeth (Ahmed 1992), and thus promote a gendersensitive reading of Islam (Mernissi 1991).

Using this dual structure and mutual dependence between structure and agency (Whittington 2010) and Islamic feminism which highlights the centrality of choice among human actors (Whittington 1992) in seeking alternative interpretations of Islam, we base our investigation on the premise that Muslim women entrepreneurs have created a particular understanding of Islam 'via producing and reproducing it [Islam] through social practices across space and time' (Uygur 2009, p.215). Our focus is on the structure's (Islam) effects on entrepreneurial behaviours and the effects of the entrepreneurs' agency and Islamic feminism on their understanding and interpretation of the structure (Islam) and its influence on their entrepreneurial experiences. Islam thus is a mediator of behaviour and an outcome of individual agency that is manifested in how the Muslim women entrepreneurs understand it. Furthermore, Islam is a feature that is available in the entrepreneurs' social setting and interacts with other features in that setting, including cultural values and norms. We, therefore, adhere to the notion that entrepreneurs and their entrepreneurial experiences cannot be described, understood, explained or even considered unless they are examined and addressed at the intersection of the various aspects of their surrounding social and cultural contexts. Structuration Theory along with Islamic feminism, therefore, are well aligned with our research aim to explore how Islam is understood in and influences the entrepreneurial experiences of Muslim women entrepreneurs in the country-specific context of Lebanon.

\section{Methodology}

We adopted an interpretive qualitative methodology, which allows us to build an understanding of the experiences of Muslim women entrepreneurs in Lebanon and to contextualize their experiences in socio-cultural, economic, and religious contexts (Cohen 2006; Tlaiss and Kauser 2018). Given our interest in understanding the role of Islam as experienced and interpreted by the women, we conducted research for and with (rather than about) our respondents (Sprague 2016; McAdam et al 2019a). In doing so, our objective was to generate new, useful, engaging insights into the lived experiences of women entrepreneurs.

\section{Empirical setting}

Lebanon was chosen as our research setting for a number of reasons. First, it is often described as a patriarchal, masculine Arab country with sociocultural values that favour a traditional division of labour and promote strictly defined gender roles (Tlaiss and Kauser 2018). Despite these restrictive social practices and cultural values, Lebanon has the highest female-to-male entrepreneur ratio in early stage entrepreneurship (69\%) among the seven Arab countries that participated in the 2017 GEM's report (Al Hussaini and Hill 2018) and the highest gender equality index based on the Arab Barometer data (Kostenko et al. 2016). Second, Lebanon is frequently referred to as the most diverse country in the Middle East, with different Muslim sects (54\%) and Christian denominations (40.5\%) (The World Fact Book 2018). Although religious practices, including daily prayers and rituals, are important to Lebanese Muslims (Pew Research Center 2018), the treatment of women is often perceived as considerably more secular than that of Muslims in neighbouring Arab 
countries. Lebanese Muslim women are free to interact with men, and the wearing of headscarves, is voluntary. A more secular setting may imply less insights into the role of Islam on entrepreneurship, as religious believers are expected to "wear their beliefs less tightly in secular societies" (Asad 2006b, p.515). However, we argue that investigating the impact of Islam on Muslim women entrepreneurs in Lebanon provides a nuanced understanding of the relationship between Islam and women's entrepreneurship in secular country settings. Further, we concur that Muslims cannot be grouped together due to the manifold differences in the way Islam is perceived and practiced among Muslims in different countries due to historic traditions, colonial legacies and levels of economic development (Norris and Inglehart 2002). In doing so, our approach highlights the heterogeneity of Islam in that "the religious and the secular are not essentially fixed categories (Asad 2003, p.25). We, therefore are confident that this geographical context is a rich research site in which to explore how Islam is understood and influences the entrepreneurial experiences of women entrepreneurs.

\section{Data collection}

To identify our research sample, we adopted a purposive sampling strategy which combined network and reference sampling (Neergaard 2007; Patton 2002). Capitalising on the first author's network, friends, and personal connections, information-rich entrepreneurs and individuals who knew Muslim women entrepreneurs and were willing to make referrals were contacted. Reference sampling, which targeted key informants or experts who were identified by the researchers as 'ideal' and possessing 'the specialized knowledge that the researcher needs' (Neergaard 2007, p.265), was also utilised. Based on studies conducted in Lebanon (Tlaiss and Kauser 2018) and elsewhere in the Arab world (McAdam et al. 2019a; Tlaiss 2015a,b), the term entrepreneur was operationalised as an individual who owned and managed a business and was self-employed. The sampling criteria focused on identifying Muslim women entrepreneurs who had founded and ran their own business, had been operating for at least five years, and had at least eight employees. As recommended by Corley and Gioia (2004), iterative data collection, which involves simultaneous data collection and analysis while recruiting new informants, was conducted until theoretical saturation was achieved (Glaser and Strauss 1967). Given that the validity of qualitative research is determined by the information-richness rather than the sample size (Patton 2002), a sample of 21 women interviewees was deemed to be sufficient. Table 1 summarises the respondents' characteristics.

\section{INSERT TABLE 1 HERE.}

The women were interviewed in person during 2017 and 2018. Data was collected through numerous meetings and subsequent telephone conversations to clarify and expand upon specific issues. All the interviews, which lasted 60-180 minutes, were tape-recorded. The women were not asked about their religiosity or their sect given the sensitivity of questions about religion, especially in Lebanon with its sectarian nature, diverse sects and the tension often generated by this religious diversity. The interviews investigated the influence of Islam on entrepreneurial experiences through open-ended questions such as: 'Does/did your religion/or the teachings of your religion influence your entrepreneurial experiences? We also asked expository questions to encourage the women to elaborate on 
their responses (e.g. 'Can you give an example or provide more details about this issue? Can you tell me more about this?'). These open-ended questions allowed the women to construct their experiences and narrate their own stories without restrictions.

Based on the interviewees' preferences, the interviews were conducted in Arabic, French or English with a significant amount of code-switching, or switching back and forth, between English and Arabic or French. To increase the validity of the translation process and eliminate translation-related problems, back translation was performed (Leitch et al. 2010). The interviews' transcripts in Arabic and French were translated into English by the first author and then back-translated into their original language by an independent trilingual academic. Trilingual academicians familiar with the topic and the subtleties of the languages were also consulted and proved to be instrumental in reducing any translation biases (Brislin et al. 1973).

\section{Data analysis}

The interviews were transcribed per verbatim and subjected to thematic analysis (Miles and Huberman 1994), along with an iterative process alternating between deduction and induction. An initial codebook was created based on the literature review (Glaser and Straus 1967; Strauss and Corbin 1990). The interview transcripts were then read and scrutinised by the researchers, who independently coded them manually. The initial list of codes was compared to those created by the researchers, and inductive coding was used to develop finer, first-order concepts (Dy et al. 2017). A constant comparison method (Glaser and Straus 1967) was used, allowing for the emergence of new codes and the constant updating and development in order to make the list of codes more comprehensive (Leitch et al. 2010). Next, following Gioia et al. (2013) and Dy et al. (2017), the theoretical relationships between the codes were considered, and these first-order codes were categorised into second-order themes and aggregated into four aggregate theoretical dimensions. The final data structure is presented in Table 2.

\section{INSERT TABLE 2 HERE.}

\section{Findings}

The four aggregate theoretical dimensions are explored in detail and illustrated with power quotes (Pratt 2009), which constitute the most insightful, concise, and persuasive evidence (Coviello 2014). Proof quotes are also utilised as a means of triangulation and to illustrate the prevalence of key findings (Pratt 2009).

\section{INSERT TABLE 3 HERE.}

\section{Islam as Raison d'etre}

The women were inspired to start their own businesses given the divinity of commercial activities and the honour associated with martyrdom in Islam. As remarked by Hala and Amal, respectively: 'Islam plays a very important part in my life and business. ... I was not happy in my employment, and then I heard it stated that on Judgment Day, the merchants will stand next to the martyrs. ... That status inspired me to start my business'. 'We as entrepreneurs are equated to martyrs. ... Martyrdom is the highest and most noble [status] in Islam. ... This status encouraged me to start my business'. This underscoring of the divine status was especially relevant as it provided the women entrepreneurs with a sense 
of wellbeing, allowing them to feel closer to God in addition to giving them a sense of social accomplishment for contributing to their local economies. Ghina explained: 'The Hadeeth says that business people or the merchants, through starting their own businesses, are serving God on earth through creating jobs, giving people employment and allowing them to create their own homes and have families. ... It is an honour and a responsibility'.

Examples of successful entrepreneurs in Islamic history were also significant, in providing further inspiration and as acting as role models to the women. The most prominent role models identified by the Lebanese women entrepreneurs were Prophet Mohamed (PBUH), and his first wife, Khadeeja, who was the wealthiest merchant in the Arabian Peninsula (Tlaiss 2015a). Aida highlighted the positive influence of Khadeeja on her: 'Our mother Khadeeja was my big inspiration. The times long ago were more difficult than today, and yet she managed to succeed and to be the wealthiest. Her wealth and reputation inspired me to be a businesswoman like her'. Neemat and Jinan both referred to the Prophet as a role model in business and life in general: 'I live by the teachings of the Prophet.... He is my role model in business and in life... The Prophet's job was that of a merchant, and this inspired me' and 'Prophet Mohamed (PBUH) is my role model ... at work and in my life in general. ... He was a trader, and he spoke highly of traders, so he was an inspiration to me'.

To avoid involvement with haram (forbidden) and become closer to God, the women embarked on their entrepreneurial journeys in the halal (lawful). A number of women in this study were previously employed in organisations (e.g. banks, insurance and hospitality) that required them to engage with companies and individuals in haram industries, such as gambling, alcohol and pork. This involvement with Haram generated guilt amongst the women. For instance, Fadwa stated: 'I was unhappy and ... did not feel like a good person or a good Muslim. ... I used to work in a bank, and I had to prepare credit files for customers who owned liquor stores or operated casinos where [there was] gambling, alcohol and pork. ... These businesses are all haram, and I did not want to work with them. ... I left my job and decided to create my own, doing halal-only business'. Rasha had a similar experience: 'I studied hospitality management at university, so I started my career in the hotel industry as a restaurant manager, but I was not comfortable. ... We served alcohol and pork. ... I used to feel that my money was all haram. ... The Quran and the Hadeeth clearly refuse that, and it is considered haram... so I left it.... And now my business has no haram in it'. Another group of women felt the money they made was haram as they were working in corrupt organisations. As Ilham illustrated: 'I used to work at a marketing company. ... We were supposed to do marketing research, but we were not doing what we would charge the client for. ... There was a lot of cheating and lying, and it felt that my money was haram... so I was not happy, and ... I started my business to get away from the haram practices and the haram money ... '. These findings do not only reflect how the women reproduced their own understandings of the structure (Islam) by approaching Islam as a source of inspiration, focusing on the availability of role models in Islamic history, and creating their own understanding of halal and haram, but also demonstrate how they capitalized on Islamic feminism in generating their own understanding of Islam as an enabler for their entrepreneurial activities. 


\section{Islam as a source of entrepreneurial resilience}

The turbulent political climate and resulting economic difficulties in Lebanon were frequently referred to by the women entrepreneurs as significant challenges hindering the growth and development of their respective enterprises. Rather than being demotivated by these conditions, the women resorted to God and Islam as sources of entrepreneurial resilience. Given their inability to change their country's economic situation, the women drew on their tawakul (trusting) in God as a means of accepting and coming to terms with these conditions. This approach was evident in Ruba's remark: 'As a Muslim, I accept the fact that God is in charge, so I do my best but know that the ultimate saying is in God's hand ... Every day, I start my day by saying "tawakalto ala Lah"'. In a similar vein, by surrendering to God as the ultimate provider, the women entrepreneurs learned to accept that everything that occurred to them and their businesses was rizq (provisions or sustenance or blessings/giving of God). Tawakul and the notion of rizq acted as calming influences on Rana and provided her with the motivation needed to persevere: 'When I started my business, everything used to stress me out. When business got slow, I used to worry about not making enough money and closing the business. ... Then I just tawaklto in God. ... God is responsible for my rizq, and whatever comes from God is good'. Our findings thus present an interconnection between Islam and entrepreneurship as tawakul and rizq provided the entrepreneurs with resilience and ability to make sense of the broader context.

The women highlighted the societal barriers and gender role stereotypes they faced, with women's roles limited to motherhood and domestic chores. This was clear in what Maha, among many others, said: 'The conservative society in Lebanon is [our problem]. Yes, women go to universities here and get degrees, but our society still thinks we are only fit to stay at home'. The women's families did not support their entrepreneurial endeavours, with household and family responsibilities seen as the responsibility of the women. The women referred to entrepreneurship as being widely perceived as a man's job and accordingly experienced a "lack of fit". To that effect Sawsan remarked "I was criticised because having a business was not a woman's job...people including my family and friends would often advise me to go home because entrepreneurship is a man's job and it is not suitable for me as a woman". Nevertheless, these women entrepreneurs capitalised on their own understanding and interpretation of Quranic verses as a means of empowerment in combating the patriarchal traditional cultural values and traditions in Lebanon. This is summed up by Fadwa - 'Islam gave me the power to fight the society...my in-laws and my parents spoke about our traditions and culture and how the place of the woman is her house... so I said that if the prophet allowed his wives to work and have businesses and go with him to war... why are you stopping me".

\section{Islam as a vehicle to personal growth}

Beyond providing a sense of inspiration and a basis for resilience, Islam's contributions to the women entrepreneurs' personal growth manifested in three ways, namely through helping others, appreciating hard work and the non-avoidance of physical work. First, through its teachings that focus on poverty mitigation, Islam made the women feel responsible for the livelihood and the survival of their employees and their families. This notion was clearly illustrated by Zeina: 'Having your own business means that you are 
responsible not only for yourself and your family but also for the livelihood of your employees and their families as well. ... This is a big responsibility. ... By keeping these guys' homes open, you are preserving their dignity and that of their children. ... This responsibility made me see my business differently and behave differently with my employees. ... It made me humble somehow'. Islam's teachings elevated the women's sense of responsibility and made them less inclined to making hasty decisions given that the survival of others depended on them. As Fatmeh remarked: 'When I started my business, I had a different perspective on work life. ... I was just thinking about myself. ... Now I feel that I have grown at a personal level. ... According to Islam, I am responsible for my employees, and I have to honour this responsibility'. Islam thus allowed the women to see their mission as entrepreneurs as one of helping others sustain their dignity as opposed to undertaking individual, personal endeavours.

Second, Islam, through the Hadeeth, emphasises the centrality of work in its followers' lives (Possumah et al. 2013). The women often referred to using hard work as a means to get closer to God, as evident in Suha's comment: 'As per the Hadeeth, I welcomed hard work as a means to succeed as nothing comes easy but also as a means to erase my sins'. These Islamic teachings (the structure) also motivated the women entrepreneurs to seek itqan (quality and excellence) in every endeavour. For instance, Malaki remarked 'Islam helped me grow personally through pushing me to work hard and to seek quality in the products and services that I give to my clients. ... It is not about delivering only, but also doing work that is motqan [adjective of the noun itqan] as per the Hadeeth'.

Third, the Quran instructs Muslims to pursue whatever work is available without differentiating between forms of work: God 'has also made subservient to you all that is in the heavens and the earth' (Quran 45:13). However, in Lebanon, physical labour was associated with lower socio-economic status, with this sentiment shared amongst the women, including Noor: 'My family was not happy with my desire to open a beauty spa and a hair salon. ... For them, it reflected negatively on our social status. ... Doing facials for clients would make them [family] look bad, ... but I did not feel ashamed. ... Islam says that any type of work that is halal is honourable'. The women utilised Islam and the Hadeeth to justify and make sense of their entrepreneurial choices and practices, even those involving physical labour (Possumah et al. 2013). For example, Suha stressed the instrumental help from Islam in overcoming societal criticism questioning her involvement in physical work: 'When we are busy, I go into the kitchen and help the chefs. ... I clean and cut vegetables, clean dishes. ... As the Quran says, "For all people, there are ranks according to their deeds" [Quran 6:132], so this gave me the power to not care.' Throughout this section, the influence of Islamic feminism is rather undisputable as the women created their own understanding of Islamic teachings which unfolded as a vehicle that fostered their personal growth.

\section{Islam as a guidebook to business growth}

The general sentiment among the women was that Islamic moral values guided them to live righteous lives. They also stressed their conviction that adhering to these teachings ensured the growth and sustainability of their entrepreneurial ventures. As Sara remarked: 'I follow the teachings of Islam. It is my source of guidance. They help me be a better person and businesswoman through guiding me not to lie or cheat or steal from my customers. ... It also guides me on how to deal with my employees and suppliers and everyone I deal with'. 
In particular, the women emphasised the importance of being honest with employees about workloads and work conditions, which helped them gain their employees' trust and commitment. Jinan explained: 'I am honest with my employees about the amount of work. ... I tell them that in the winter things are slow, and people do not buy houses, and the commission is low, but in the summer, we work long hours and even on weekends'. The women also stressed the importance of extending compassion and empathy to their employees, forgiving their mistakes, allocating acceptable work burdens and paying them fairly. This approach to employees was evident in Sawsan's statement: 'The Hadeeth is clear: You have to pay the worker before his sweat dries, and this is what I do. ... I might not pay myself for several weeks but never my employees. ... I pay them what they deserve, so my salaries are very fair and even more than market rates'. Furthermore, some women spoke about the need to treat their employees as family, fostering teamwork and even sharing profits with their employees whom they considered to be their partners: 'Our employees are our partners. ... When the business makes money, it is because of their work, so according to Islam, I have to share this profit with them, or else it is haram, and I wouldn't be fair with them' (Noha).

Similarly, the women emphasised their need to make halal money by being fair and honest in all their interactions with their suppliers and their debtors, honouring commitments and making payments on time. As Ghina remarked: 'Mohamed (PBUH) was referred to as honest and truthful. ... I always make sure that I am honest with my suppliers, and I always pay when I promise'. The women also stressed the need to be ethical and respectful when dealing with competitors, in particular by avoiding price wars, not spreading rumours or gossip and by engaging in fair competition: 'My faith prevents me from spreading rumours among my competitors. ... Although they do that about my pharmacy, my Islam[ic faith] prevents me from reciprocating' (Mona).

Islamic values also governed the relationships between the women entrepreneurs and their clients. The women emphasised honesty in their interactions with their clients in order to build relationships based on trust. They stressed the role of transparency and told how they explained to their clients the specifications and usage of the products and services they were offering without exaggerating the benefits or ignoring any defects or shortages. As stated by Maha, 'some of my products are locally made, and others are imported. I tell my clients the truth about the items and their prices.... I do not cheat and say it is imported [when it is] locally made'. The women also stressed the importance of charging fair prices that allowed them to achieve acceptable profit margins without overcharging their clients. For example, Fatmeh, the owner of a nursery, emphasised transparency with her clients when discussing profit margins: 'My price is fixed and the same regardless of whether my client is rich or not.... When I get a client who argues with me about the price, I show her how much her child costs me per month and how much money is left for me. ... I have nothing to hide'. As per Giddens (Giddens 1984), the women used their agency and their Islamic feminist understanding of Islam to demonstrate how their own understandings of the structure (Islam) facilitated the growth of their businesses.

\section{Discussion}

This paper sought to attend to the dearth of research on the influence of Islam on the entrepreneurial experiences of Arab women by focusing on women entrepreneurs and their interpretation of Islamic teachings in order to support their entrepreneurial decisions and 
practices. Our four aggregate dimensions provide insights into the lived experiences of being Muslim, a woman, and an entrepreneur in a secular country within the Arab world. Although this contradicts claims that people in secular settings live their faith lightly (Asad 2003), the nuances that our findings reveal provide insights into how the secular nature of Lebanese society influences the agency of the women and their liberal (Islamic feminist) interpretation and understanding of Islam.

It is rather undisputable that a traditional, conservative interpretation of Islam can hinder women's entrepreneurship (Essers and Benschop 2009; Madichie and Gallant 2012; Tlaiss 2015a). However, in this study, Islam unfolded as a vehicle supporting Muslim women's entrepreneurship based predominantly on the Islamic feminist approach that they adhered to in approaching the teachings of their faith. The women entrepreneurs in this study, equipped by relatively higher levels of education and "less tight" (Asad 2006b) religious beliefs expressed a deep understanding of Islamic feminism, with several of the women explicitly identifying themselves as Islamic feminists. Capitalizing on their feminist interpretation of Islam, the women performed gender as a situated practice in Lebanon, between the social constructs of Islam and the patriarchy of the Arab culture. They stressed the existence of two Islams with a gulf in-between; (1) an Islam that they affiliate with, that is based on their own readings of the Quran and the ethical approach to Islam and (2) the institutionalized Islam that they find difficult to relate to. The distinction between two forms of or approaches to Islam resonates with Ahmed's (1992, p.226).) "Lay Islam" versus "Islam of the politically powerful...intolerant to all understandings of the religion except its own... and hostile to women".

Based on their own ethical readings of Islam, the women experienced entrepreneurship as a calling based on three Islamic pillars. First, they were inspired to be entrepreneurs by the divinity attributed to entrepreneurs and the act of entrepreneurship by Islam. Although the divinity of the act of entrepreneurship has been referred to in previous studies (Ali and Al Owaihan 2008; Basit 2012; Tlaiss 2015a), the novelty of our findings lies in how the women's entrepreneurial activities unfolded in response to this divine calling, further inspiring and encouraging them to create their own businesses. Second, the availability in Islamic history of successful entrepreneurs to act as role models for contemporary women entrepreneurs also inspired them to embark on their respective entrepreneurial journeys. Although Mohamed's (PBUH) importance as an exemplar of high morals and virtuous behaviour (Basit 2012) as well as his less virtuous behaviours (Gordon 1989; Willis 1985) have been stressed elsewhere in the literature, the women in this study underscored the Prophet as an entrepreneurial role model and as a supporter of women's rights given that an important part of his legacy lies in ending infanticide of females that was common in the Arabian Peninsula. Similarly, although the significance of Khadeeja and the Prophet's wives has been stressed in previous studies on Islam and entrepreneurship (Madichie and Gallant 2012; Tlaiss 2015a,b), our findings build on this significance by empirically demonstrating that Khadeeja's influence extended beyond being an example of a strong woman in Islamic history to that of being a role model and a source of inspiration for other Muslim women engaging in entrepreneurial activities. Third, Islamic teachings clearly prohibit Muslims from making a living from haram transactions or employment (Murtaza et al. 2016; Possumah et al. 2013), accordingly these teachings inspired the women entrepreneurs to start their own businesses in halal (non-haram) sectors. Our findings thus offer a nuance of a direct link between the notion of "halal" as 
inspiration for entrepreneurial practices in comparison to previous studies that have focused on the halal notion within the context of the growth of halal food industries and businesses on a global scale (Gümüsay 2015; Uygur 2009). Furthermore, Madichie and Gallant (2012) highlight the role of discriminatory organisational structures and practices as push factors encouraging Arab women into entrepreneurship. We build on this insight by empirically demonstrating how the specific Islamic principles of halal and haram unfolded as push factors driving and inspiring Muslim women entrepreneurs away from organisational employment towards entrepreneurship in halal areas.

In aligning with our structuration perspective, it is important to highlight the mutual dependence between structure and agency (Whittington 1992), whereby the women (agents), as per structuration theory (Giddens 1984), drew on and were inspired by their own readings of the privileged status that Islam (structure) granted entrepreneurs through the Hadeeth. Agentically, the women entrepreneurs reproduced their own understanding of the structure (Islamic equality between martyrdom and merchants) as a source of inspiration. The women also exercised their agency through reproducing their own understandings of the structure (Islam) by focusing on the availability of role models in Islamic history as enablers for their entrepreneurial activities. They also extended their understanding of the notions of halal and haram to their choice of work, further highlighting the centrality of choice among human actors (Whittington 1992). In other words, given that Islam through its teachings (structure) forbids haram activities, this structure interacted with the women's agency in reading the Quran and lack of satisfaction with haram work and unfolded in the form of inspiration i.e. new business creation.

Another interconnection that emerged from this research centres upon how Islam, through the notions of tawakul and rizq, unfolded as major source of motivation and resilience for women entrepreneurs to persevere despite constraining economic, political and sociocultural conditions. Although previous studies have referred to rizq and itqan as ethical values sought by Muslims to improve their business performance (Hassi 2012; Possumah et al. 2013) and have reflected on the importance of resilience in entrepreneurship in danger zone countries (Bullough et al. 2014), as well as the distinct aspects of entrepreneurship associated with entrepreneurial resilience (Hayward et al. 2010; Ungar et al. 2007), the findings of this study extend this nascent stream of research on resilience and entrepreneurship by demonstrating the role of Islam as an antecedent for women's resilience. Reflecting on structuration theory and the mutual dependence between structure and agency (Whittington 2010), the women in this study "reproduced Islam" (Uygur 2009, p. 215) through extending the reading and associations of rizq and tawakul, through their agency, into an empowering means to help them persevere with their entrepreneurial endeavours in the face of dire political and economic country-level conditions.

Islam also unfolded as a means by which the women made sense of the sociocultural restrictions that they encountered. To further explain, although the women entrepreneurs highlighted the empowering contribution of Islam to their lives and entrepreneurship activities, the agentic approach that they adhered to in explaining Islamic teachings (Islamic feminism) is not to be mistaken as the absence of tension. On the contrary, our women faced significant difficulties adhering to their choice of entrepreneurial work. Although, entrepreneurship has been held up as a panacea to challenge the subordination of women via the promise of autonomy and independence, it 
is important to note that such subordination is deeply embedded within historical socioeconomic contexts which informs and reproduces normative, hierarchies and patriarchies which are unlikely to be addressed by new venture creation alone (Ogbor 2000; Marlow and McAdam 2013; McAdam 2013).

In addition to having to stand against socio-cultural, patriarchal values that adhere to the ideology of subordinating women (Tlaiss and Kauser 2018), the interviewees had to navigate conservative interpretations of Islam that are considered as equally viable (Asad 1986). Through emphasizing the individuality of their faith, the women navigated sociocultural patriarchal barriers and the conservatist interpretations of Islam and in so doing legitimised their entrepreneurial activities. Furthermore, through invoking and reproducing their own interpretations of Islam, they silenced their religious and socio-cultural critics and justified their entrepreneurial desires and pursuits. Collectively, as per structuration theory (Giddens 1984), we demonstrate how the women entrepreneurs gained entrepreneurial resilience through the exercise of their agency, combined with their deep knowledge of Islamic history and teachings that served to support their right to entrepreneurship, and their choice of the feminist interpretation of the Quran and the Hadeeth (structure).

Based on our findings, the contributions of Islam to the women's personal lives, growth and development as entrepreneurs and as human beings were multifaceted and extended beyond being a source of inspiration and motivation. As per structuration theory (Giddens, 1986), through their Islamic feminism, the women in this study reproduced the structural notions of Islam as enablers of personal growth through helping others, appreciating hard work and the non-avoidance of physical work. According to Islam, alleviation of poverty through business creation and employment is a fundamental reason to pursue business activities (Ali and Al Owaihan 2008; Tlaiss 2015a). This view is confirmed by the Hadeeth that 'the best of people are those who benefit others' (Ali and Al Owaihan 2008). Leaning on their individual interpretations of Islam, the women extended their responsibility towards their employees whereby through the provision of employment, they were helping other human beings and contributing to the preservation of their employees and families' human dignity.

Accordingly, we suggest a new interconnection between Islam and entrepreneurship in an Arab context, one that is built around the notion that in Islam, entrepreneurs are not only business owners but also providers of income and dignity. We also put forward the experience of entrepreneurship as a form of preserving others' dignity. The women also experienced personal growth through exercising hard work and itqan. Although hard work in Islam is perceived as a means to absolve sins (Ali and Al Owaihan 2008) and aligns itqan with faith (Hammoudeh 2012), the women entrepreneurs extended their structural meaning and influence, and experienced them as a means of getting closer to God and personal growth. We thus concur with Gümüsay (2015) and Possumah et al. (2013) on the importance of hard work and itqan in Islam and demonstrate the role of women (agents) in extending the role of Hadeeth from mere advice into a mechanism for realizing personal growth: 'When one of you is doing something, let him do it in the most excellent manner'. The women associated physical work with pride rather than shame through their agentic interpretations of Islamic teachings (Giddens, 1989), and in so doing reproduced conditions that facilitated their entrepreneurial activities in the face of societal 
views associating physical work with disgrace. Accordingly, we present insights arguing that Islam helped the women fight the social stigmas associated with manual work in the Arab context by endowing them with pride in partaking it.

In contrast to previous studies that associate low business growth in Muslim countries with Islamic teachings (Weber 1905, 1930), the women in this study did not believe that Islam was opposed to the development and growth of their enterprises. On the contrary, and as per other Islamic feminists (Badras 2002; Wadud 1999), they believed that their businesses have developed as a result of the guidance provided by Islamic rules and Quranic teachings. Hence, they spoke about how values highlighted in Islam, especially those related to honesty, truthfulness and fairness (Ali and Al Owaihan 2008; Beekun 2012), guided them towards sound business actions, ethical profit-making and friendly honest relationships with all stakeholders. With regards to employees, the women highlighted the need to treat them with fairness, compassion and empathy as per Islamic teachings. Hence, their approach to their employees resonates with that highlighted in other studies (Karakas et al. 2015; Murtaza et al. 2016; Possumah et al. 2013; Uygur 2009). However, this study extends the connection between Islam (structure) and business management by demonstrating that the women entrepreneurs sought to create a sense of community among their employees through making the workplace a safe place where dignity was protected and respected. The women also portrayed advanced business thinking by practicing "profit-sharing" which is often the domain of big organizations. Furthermore, they accepted the rules of Islam as a means to grow their businesses. The women also emphasised the need to take a balanced approach with their stakeholders that is built on Islamic moral values and ethics. Accordingly, they stressed not only the importance of Islamic values of honesty and trustfulness with suppliers, clients, and in the market place (Ali and Al Owaihan 2008; Hammoudeh 2012; Ismaeel and Blaim 2012), but also the importance of adopting a balanced approach towards all stakeholders; one that is built on honesty as a catalyst fostering the growth of the enterprises of women entrepreneurs in Lebanon.

\section{Conclusion}

In this paper, we explored how Islam is understood by women entrepreneurs and its influence on their entrepreneurial experiences in the country-specific context of Lebanon. Accordingly, we present empirical evidence detailing how women entrepreneurs draw on various aspects and teachings of Islam to make sense of their entrepreneurial decisions within the context of restrictive social and cultural practices. We thus provide insight into how women's entrepreneurship interlocks with Islamic teachings and the restrictions imposed by patriarchal sociocultural values within the country-specific context of Lebanon. This paper advances entrepreneurship research by demonstrating how Islam unfolds as a source of inspiration and resilience for women entrepreneurs, if and when equipped with an Islamic feminist interpretation.

Within this paper we make the following theoretical contributions. First, we contribute to research on Islamic entrepreneurship through revealing several new interconnections between Islam and entrepreneurship. These interconnections are significant and extend the extant literature on Islam and entrepreneurship which to date has focused on the nature of Islamic business and ethical behaviour (Gümüsay 2015; Possumah et al. 2013). Accordingly, we highlight the role of Islamic feminism and demonstrate how a feminist interpretation of Islam can provide creative solutions to the economic, political 
and societal problems faced by Muslim women entrepreneurs. Although we acknowledge that that the positive influence of Islam on women's entrepreneurship may be marginal given the predominant salience of the conservative interpretations of Islam worldwide, we provide a more nuanced understanding of the dominant discursive ways through which Islam extends and influences women entrepreneurs' personal and business lives.

Second, we contribute to women's entrepreneurship studies by denying the notion that gender is the property of entrepreneurial women in developed economies (Marlow et al. 2018), and by acknowledging that Islam has many varied interpretations across national contexts (Karakas et al. 2015). Accordingly, we argue that secularism, and the Western influence it embodies (Asad 2003, 2006) in terms of gender equality and women's empowerment, significantly impacted the women's agency and their choice of liberal, feminist interpretations of Islamic teachings, as well as Lebanese society's acceptance of these non-traditional examples of women. In other words, we argue that the secular context of Lebanon, along with the interviewees' relatively high level of education, further paved the way for the Lebanese women to equip themselves with the feminist, liberal interpretation of Islam in the face of the conservative readings of gender in Islam in order to obtain agency. In so doing, the women in this study performed gender as a situated social practice within the context of their socio-cultural values, secular society, through their own understanding of Islam as fuelled by their agency. Thus, they built their entrepreneurial activities and enterprises at the interstices between the "Muslim" and the "secular" as they engaged in complying with, challenging, and resisting of the frameworks offered by these two worlds.

Third, we extend previous studies on entrepreneurial resilience (Branzei and Abdelnour 2010; Dewald and Bowen 2010) by focusing on women entrepreneurs as an individual unit of analysis and by showing how Islamic tawakul and rizq enabled the women entrepreneurs to overcome obstacles and challenges while remaining optimistic in the face of economic and political adversity. Although Ungar et al. (2007) argued that adherence to one's local cultural practices, values and beliefs is an aspect of resilience, we demonstrate that the women realised entrepreneurial resilience through rejecting the sociocultural values of their context via Islamic feminism. In other words, we show how an Islamic feminist interpretation of Islamic teachings, provided the women with entrepreneurial resilience within the context of adverse socio-cultural barriers and masculine stereotypes.

Our study of Islam's influence on women's entrepreneurship in the context of the Arab region suggests a number of avenues for future research. First, while in-depth interviews were used to gain insights into the entrepreneurial experiences of the Muslim women entrepreneurs within the Lebanese cultural context, future research could investigate how Islam affects women Muslim entrepreneurs in different geo-political and socio-cultural contexts. Such efforts would provide a better understanding of the different interpretations of Islam and their influences on entrepreneurs' experiences. Second, while this research explored the role of Islam without measuring or accounting for the interviewees' religiosity, some evidence suggests that Islam's influence on Muslims' entrepreneurial experiences varies by level of religiosity (Uygur 2009). Accordingly, we propose that future researchers should consider using quantitative approaches to measure entrepreneurs' religiosity and its impact on entrepreneurial behaviour, intentions and motivations. Third, acknowledging the ongoing debate in qualitative research with regards 
to 'matching' the interviewer and interviewee using specific categories such as ethnicity, gender, class, age (Golombisky 2006), future research is needed to understand how Islam is experienced by Muslim male entrepreneurs in the Arab region.

\section{Endnotes}

*PBUH: Peace be upon him. Following Beekun and Badawi (2005), PBUH is an honorific used whenever the name of the Prophet is mentioned throughout the article

**: The Quran is composed of chapters and verses. All references made to the Quran throughout this study following this form: chapter number:verse number within that specific chapter. Per Tlaiss' (2015a) suggestions we referenced the following translation of the Quran: Saheeh International (Eds): 2004, The Qur'an (Al-Muntada al-Islami)

Ethical approval: All procedures performed in studies involving human participants were in accordance with the ethical standards of the institutional and national research committees and with the 1964 Helsinki declaration and its later amendments or comparable ethical standards.

\section{References}

Ahmed, L. (1992). Women and Gender in Islam: Historical Roots of a Modern Debate. Yale University Press, Yale.

Al-Dajani, H., \& Marlow, S. (2010). Impact of women's home-based enterprise on family dynamics: Evidence from Jordan. International Small Business Journal, 28(5), 470-486.

Al Hussaini, W., \& Hill, S. (2018). Global Entrepreneurship Monitor (GEM) 2018. National Report Lebanon 2017. Accessed August, 2018. https://www.gemconsortium.org/country-profile/131

Ali, A. J., \& AlOwaihan, A. (2008). Islamic work ethic: a critical review. Cross cultural management: An international Journal, 15(1), 5-19.

Arkoun, M. (1994). Rethinking Islam: Common questions, Uncommon answers, today. Westview Press, Boulder.

Asad, T. (1986). The idea of an anthropology of Islam. Occasional Paper Series. Washington DC: Institute of Contemporary Arab Studies at Georgetown University.

Asad, T. (2003). Formations of the secular: Christianity, Islam, modernity. Stanford University Press, Stanford, CA. 
Asad, T. (2006). Responses in David Scott and Charles Hirschkind (eds) Powers of the secular modern: Talal Asad and his interlocutors, 206-241. Stanford University press, Stanford, CA.

Badran, M. (2005). Between Secular and Islamic Feminism/s: Reflections on the Middle East and Beyond. Journal of Middle East Women's Studies, 1(1), 6-28

Badran, M. (2009). Feminism in Islam: Secular and Religious Convergences. Oneworld Publication, Oxford.

Barlas, A. (2002). Believing Women in Islam: Unreading Patriarchal Interpretations of the Qur'an. University of Texas Press, Texas.

Basit, A. A. (2012). Critical review of Hadeeth. In A. Basit (Eds.), The Global Muslim Community at a Cross-Roads: Understanding Religious Beliefs, Practices, and Inflighting to End the Conflict, (pp. 27-32). ABC-CLIO, LLC, Santa Barbara, California.

Beekun, R., \& Badawi, J. (2005). Balancing ethical responsibility among multiple organization stakeholders: the Islamic perspective. Journal of Business Ethics, 60, 131-145.

Beekun, R. (2012). Character center leadership: Mohamad (p) as an ethical role model for CEOs. Journal of Management Development, 31(10), 1003-1020.

Branzei, O., \& Abdelnour, S. (2010). Another day, another dollar: Enterprise resilience under terrorism in developing countries. Journal of International Business Studies, 41(5), 804-825.

Brislin, R. W., Lonner, W., \& Thorndike, R. (1973). Cross-cultural methods. Publication John Wiley and Sons, New York.

Bullough, A., Renko, M., \& Myatt, T. (2014). Danger zone entrepreneurs: The importance of resilience and self-efficacy for entrepreneurial intentions. Entrepreneurship Theory and Practice, 38(3), 473-499.

Butler, J. (1993). Critically queer. GLQ: A journal of Lesbian and Gay Studies, 1(1), 1732.

Cohen, L. (2006). Remembrance of past things: Cultural process and practice in the analysis of career stories. Journal of Vocational Behavior, 69, 189-209.

Corley, K. G., \& Gioia, D. A. (2004). Identity ambiguity and change in the wake of a corporate spin-off. Administrative Science Quarterly, 49(2), 173-208.

Cornwall, J. R., \& Naughton, M. J. (2003). Who is the good entrepreneur? An exploration within the Catholic social tradition. Journal of Business Ethics, 44(1), 61-75. 
Coviello, N. (2014). "How to Publish Qualitative Entrepreneurship Research. In Fayolle, A. and Wright, M. (Eds), How to Get Published in the Best Entrepreneurship Journals: A Guide to Steer Your Academic Career (167-182). Edward Elgar, Cheltenham, UK.

Dana, L.P. (2009). Religion as an exploratory variable for entrepreneurship. Journal of Entrepreneurship and Innovation, 10 (2), 87-99.

De Clercq, D. and Voronov, M., (2009). Toward a practice perspective of entrepreneurship: Entrepreneurial legitimacy as habitus. International Small Business Journal, 27(4), pp.395-419.

Dewald, J., \& Bowen, F. (2010). Storm clouds and silver linings: Responding to disruptive innovations through cognitive resilience. Entrepreneurship Theory and Practice, 34(1), 197-218.

Dy, A. M., Marlow, S., \& Martin, L. (2017). A Web of opportunity or the same old story? Women digital entrepreneurs and intersectionality theory. Human Relations, 70(3), 286-311.

Essers, C., \& Benschop, Y. (2009). Muslim businesswomen doing boundary work: The negotiation of Islam, gender and ethnicity within entrepreneurial contexts. Human Relations, 62(3), 403-423.

Giddens, A. (1984). The construction of society. Cambridge, Polity

Gioia, D. A., Corley, K. G., \& Hamilton, A. L. (2013). Seeking qualitative rigor in inductive research: Notes on the Gioia methodology. Organizational Research Methods, 16(1), 15-31.

Glaser, B. and Strauss, A. (1967). The Discovery of Grounded Theory. Aldine, Chicago, IL.

Golombisky, K. (2006). Gendering the interview: Feminist reflections on gender as performance in research. Women's Studies in Communication 29 (2): 165-192.

Gordon, M (1989). The Attitude of Islam Toward Slavery. In Gordon, M. Slavery in the Arab World. Rowman \& Littlefield, New York. pp. 18-47.

Gümüsay, A. A. (2015). Entrepreneurship from an Islamic perspective. Journal of Business Ethics, 130(1), 199-208.

Hammoudeh, M.M. (2012). Islamic values and Management Practices: Quality and transformation in the Arab world. Gower Publishing Limited, Surrey, England 
Hayward, M. L., Forster, W. R., Sarasvathy, S. D., \& Fredrickson, B. L. (2010). Beyond hubris: How highly confident entrepreneurs rebound to venture again. Journal of Business Venturing, 25(6), 569-578.

Henry, C., Foss, L., Fayolle, A., Walker, E., \& Duffy, S. (2015). Entrepreneurial leadership and gender: Exploring theory and practice in global contexts. Journal of Small Business Management, 53(3), 581-586.

Ismaeel, M., \& Blaim, K. (2012). Toward applied Islamic business ethics: Responsible halal business, Journal of Management Development, 31(10), 1090-1100.

Karakas, F., Sarigollu, E., \& Kavas, M. (2015). Discourses of collective spirituality and Turkish Islamic ethics: An inquiry into transcendence, connectedness, and virtuousness in Anatolian tigers. Journal of Business Ethics, 129(4), 811-822.

Karmi, G. (1996). Women, Islam and patriarchalism. In Yamani, M. (Ed), Feminism and Islam. New York University Press, New York, NY.

Kayed, R. N., \& Hassan, M. K. (2010). Islamic entrepreneurship: A case study of Saudi Arabia. Journal of developmental entrepreneurship, 15(04), 379-413.

Kazemi, F. (2000). Gender, Islam and politics. Social Research, 67(2), 453-474.

Kelan, E. K. (2009). Gender fatigue: The ideological dilemma of gender neutrality and discrimination in organizations. Canadian Journal of Administrative Sciences/Revue Canadienne des Sciences de l'Administration, 26(3), 197-210.

Kostenko, V. V., Kuzmuchev, P. A., \& Ponarin, E. D. (2016). Attitudes towards gender equality and perception of democracy in the Arab world. Democratization, 23(5), 862-891.

Kuran, T. (2003). The Islamic commercial crisis: institutional roots of economic underdevelopment in the Middle East. The Journal of Economic History, 63(2), 414-446.

Kuran, T. (2004). Islam and Mammon: The economic predicaments of Islamism. Princeton University Press, US.

Leitch, C.M., Hill, F.M. \& Harrison, R.T. (2010). The philosophy and practice of interpretivist research in entrepreneurship: Quality, validation, and trust. Organizational Research Methods, 13(1), 67-84.

Madichie, N.O., \& Gallant, M. (2012). Broken silence: a commentary on women's entrepreneurship in the United Arab Emirates. Journal of Entrepreneurship and Innovation, 13 (2), 81-92. 
Marlow, S. and McAdam, M., (2013). Gender and entrepreneurship: Advancing debate and challenging myths; exploring the mystery of the under-performing female entrepreneur. International Journal of Entrepreneurial Behavior \& Research, 19(1), pp.114-124.

Marlow, S., Greene, F. J., \& Coad, A. (2018). Advancing gendered analyses of entrepreneurship: A critical exploration of entrepreneurial activity among gay men and lesbian women. British Journal of Management, 29(1), 118-135.

McAdam, M., (2013). Female Entrepreneurship. Routledge, London.

McAdam, M., Crowley, C. and Harrison, R.T., (2019a). "To boldly go where no [man] has gone before"-Institutional voids and the development of women's digital entrepreneurship. Technological Forecasting and Social Change, 146, pp.912-922.

McAdam, M., Harrison, R.T. and Leitch, C.M., (2019b). Stories from the field: Women's networking as gender capital in entrepreneurial ecosystems. Small Business Economics, 53(2), pp.459-474.

Mernissi, F. (1996). Women's rebellion and Islamic memory. Zed Books, London.

Mernissi, F. (1991). The Veil and Male Elite: A Feminist Interpretation of Islam. Perseus Books Publishing, UK.

Miles, M.B., \& Huberman, A.M. (1994). Qualitative Data analysis: An Expanded Sourcebook (second edition). Sage Publications, Thousand Oaks, CA.

Murtaza, G., Abbas, M., Raja, U., Roques, O., Khalid, A., \& Mushtaq, R. (2016). Impact of Islamic work ethics on organizational citizenship behaviors and knowledgesharing behaviors. Journal of Business Ethics, 133(2), 325-333.

Neergaard H (2007) Sampling in Entrepreneurial Settings. In: Neergaard H, Ulhøi J (eds) Handbook of Qualitative Research Methods in Entrepreneurship (253-278). Edward Elgar, Cheltenham, UK.

Norris, P., \& Inglehart, R. (2002). Islamic culture and democracy: Testing the clash of civilizations' thesis. Comparative Sociology, 1(3-4), 235-263.

Norris, P. (2009). Why do Arab states lag the world in gender equality? HKS Faculty Research Working Paper Series RWP09-020, John F. Kennedy School of Government, Harvard University. https://papers.ssrn.com/sol3/papers.cfm?abstract $\mathrm{id}=1474820$

Ogbor, J.O. (2000). Mythicizing and reification in entrepreneurial discourse: Ideologycritique of entrepreneurial studies. Journal of Management Studies, 37(5), pp.605635. 
Parboteeah, K. P., Hoegl, M., \& Cullen, J. B. (2008). Ethics and religion: An empirical test of a multidimensional model. Journal of Business Ethics, 80(2), 387-398.

Patton, M. (2002). Qualitative Research and Evaluative Methods (third edition). Sage, London.

Pew Research Center (2018). The Age Gap in Religion Around the World. http://www.pewforum.org/wpcontent/uploads/sites/7/2018/06/ReligiousCommitment-FULL-WEB.pdf. Accessed 10/10/2018.

Possumah, B.T., Ismali, A.G., \& Shahimi, S. (2013). Bringing work back in Islamic ethics. Journal of Business Ethics, 112(2), 257-270

Pratt, M. (2009). For the Lack of a Boilerplate: Tips on Writing up (And Reviewing) Qualitative Research. Academy of Management Journal, 52 (5), 856-862.

Roomi, M., \& Harrison, P. (2010). Behind the veil: women-only entrepreneurship training in Pakistan. International Journal of Gender and Entrepreneurship, 2(2), 150-172.

Sidani, Y. (2005). Women, work, and Islam in Arab societies. Women in Management Review, 20(7), 498-512.

Smith, B. R., Conger, M. J., McMullen, J. S., \& Neubert, M. J. (2019). Why believe? The promise of research on the role of religion in entrepreneurial action. Journal of Business Venturing Insights, 11, e00119.

Sprague, J. (2016) Feminist Methodologies for Critical Researchers. 2nd Edition. Rowan \& Littlefield, London, UK.

Strauss, A., \& Corbin, J. (1990). Basics of Qualitative Research: Grounded Theory Procedures and Techniques. Sage, Newbury Park, CA.

The World Fact Book, CIA 2018. https://www.cia.gov/library/publications/the-worldfactbook/geos/le.html. Accessed 10/10/2018

Tlaiss, H. (2014). Between the traditional and the contemporary: Careers of women from a developing Middle Eastern country perspective. International Journal of Human Resource Management, 25 (20), 2858-880.

Tlaiss, H. (2015a). How Islamic Business Ethics Impact Women Entrepreneurs: Insight from Four Arab Middle Eastern Countries. Journal of Business Ethics, 129 (4), 859-877. 
Tlaiss, H. (2015b). Entrepreneurial motivations of women: Evidence from the United Arab Emirates, International Small Business Journal, 33(5), 562-81

Tlaiss, H. and Kauser, S. (2018). Entrepreneurial Leadership, Patriarchy, and Gender in the Arab World: Lebanon in Focus. Journal of Small Business Management. DOI: $10.1111 / \mathrm{jsbm} .12397$

Ungar, M., Brown, M., Liebenberg, L., Othman, R., Kwong, W. M., Armstrong, M., \& Gilgun, J. (2007). Unique pathways to resilience across cultures. Adolescence, 42(166), 287-311.

Uygur, S. (2009). The Islamic work ethic and the emergence of Turkish SME ownermanagers. Journal of Business Ethics, 88(1), 211-225.

Wadud, A. (1999). Qur'an and Women: Rereading the Sacred Text from a Woman's Perspective. Oxford University Press, United Kingdom

Weber, M. (1905). The Protestant ethic and the spirit of capitalism. Allen \& Unwin.

Weber, M. (1930). The Protestant ethic and the spirit of capitalism, translated by T. Parsons. New York: Scribner.

Whittington, R. (1992). Putting Giddens into action: social systems and managerial agency. Journal of Management Studies, 29(6), 693-712.

Whittington, R. (2010). Giddens, structuration theory and strategy as practice. In Golsorkhi, D., Rouleau, L., Seidl, D., \& Vaara, E. (Eds.), Cambridge handbook of strategy as practice, (2010). Cambridge handbook of strategy as practice (109126). Cambridge University Press, Cambridge.

Willis, J, (1985). Slaves and Slavery in Muslim Africa: The Servile Estate. 2. Routledge, New York. pp. vii-xi. 